\title{
Organizational and Legal Principles of Ensuring Academic Autonomy of Higher Educational Institutions
}

\section{Організаційно-правові засади забезпечення академічної автономії закладів вищої освіти}

\section{Principios organizativos y legales para garantizar la autonomía académica de las instituciones de educación superior}

Received: June 16, 2020

Accepted: August 23, 2020

\author{
Written by: \\ Svitlana Viktorivna Yevdokimenko ${ }^{19}$ \\ https://orcid.org/0000-0003-2924-6621 \\ Mykola Ivanovich Inshyn ${ }^{20}$ \\ https://orcid.org/0000-0002-9332-0286 \\ Olena Salmanova ${ }^{21}$ \\ https://orcid.org/0000-0002-6376-1160 \\ Andriy Polstyanoy ${ }^{22}$ \\ https://orcid.org/0000-0002-6513-1533
}

\begin{abstract}
The objective of the article is to determine the content and specific features of organizational and legal principles for ensuring the academic autonomy of higher educational institutions. In order to achieve this objective, the authors used the following methods of scientific cognition: dialectical, formal and legal, bibliographic.

Problematic issues that are directly related to the implementation of legal norms for ensuring academic autonomy of higher educational institutions have been studied. The authors have formed own definitions of such concepts as "academic autonomy of educational institutions", "organizational provision of academic autonomy" and "legal provision of academic autonomy". Historical stages of formation and development of academic autonomy have been considered. Foreign and international norms regarding the observance of academic freedom and honesty in the most developed democratic countries of the world have been characterized. Suggestions for improving academic mobility, academic autonomy and academic freedom both in Ukraine and in the world have been provided.
\end{abstract}

Анотація

\footnotetext{
${ }^{19}$ Doctor of Law, Assistant Professor, Head of Continuing Education Department Hon. Prof. M. S. Bokarius Kharkiv Research Institute of Forensic Examinations of the Ministry of Justice of Ukraine.

${ }^{20}$ Doctor of Jurisprudence, Professor, Academician of the National Academy of Science of Ukraine, Honored Lawyer of Ukraine, Labor and Social Security Law of Taras Shevchenko National University of Kyiv.

${ }^{21}$ Doctor of Jurisprudence, Professor, Honored Worker of Education of Ukraine, Head of the Department of Administrative Law and Process of Kharkiv National University of Internal Affairs.

${ }^{22}$ Assistant of the Medical Faculty, Kharkiv National University named after V.N. Karazin.
} 
Key words: academic autonomy, higher education, legal principles, legislative provision, educational institutions, educational system.
Ключові слова: академічна автономія, вища освіта, правові засади, законодавче забезпечення, навчальні заклади, освітня система.

\section{Resumen}

El objetivo del artículo es determinar el contenido y las particularidades de los principios organizativos y legales para asegurar la autonomía académica de las instituciones de educación superior. Para lograr este objetivo, los autores utilizaron los siguientes métodos de cognición científica: dialéctico, formal y legal, bibliográfico.

Se han estudiado cuestiones problemáticas que están directamente relacionadas con la implementación de las normas legales para asegurar la autonomía académica de las instituciones de educación superior. Los autores han elaborado definiciones propias de conceptos tales como "autonomía académica de las instituciones educativas", "provisión organizativa de autonomía académica" y "provisión legal de autonomía académica". Se han considerado etapas históricas de formación y desarrollo de la autonomía académica. Se han caracterizado las normas extranjeras e internacionales sobre la observancia de la libertad académica y la honestidad en los países democráticos más desarrollados del mundo. Se han proporcionado sugerencias para mejorar la movilidad académica, la autonomía académica y la libertad académica tanto en Ucrania como en el mundo.

Palabras clave: autonomía académica, educación superior, principios legales, disposición legislativa, instituciones educativas, sistema educativo.

\section{Introduction}

The possibility of successful and unlimited existence of the institution of free thought and free expression in the state is one of the most important components of its well-being and progressive development.

As the editors say Bilgrami A. and Cole J. (2015): "No freedom can be taken for granted, even in the most well-functioning of formal democracies. Exposing the tendencies that undermine freedom of inquiry and their hidden sources and widespread implications is in itself an exercise in and for democracy". Since it is well-known fact that real scientific discoveries and significant achievements are possible only if researchers and scholars have no fear of their own judgments and statements, there are no barriers to legitimate professional activity.

As Moshman D. (2017) quite rightly noted, academic freedom is defined as the freedom to do academic work. It follows that academic freedom (1) includes freedoms of teaching, learning, and inquiry; (2) is a type of intellectual freedom; (3) is specific to academic roles and contexts; (4) is crucial at all levels of education and in all other academic contexts; (5) is individual, collective, and institutional; and (6) is central to the academic integrity of any academic endeavor or institution. This conception, which coordinates multiple traditions and literatures, enables us to explain the nature and limits of academic freedom and to justify it as a necessity for academic work.

There has been pressure on the authorities for years to enshrine mechanisms of protecting academic freedom and integrity in national law in Ukraine, whose citizens prefer to live in a developed democratic country with the real rule of law and be members of one European family sharing common values.

\section{Theoretical framework}

The importance of successfully solving the problems related to the proper and comprehensive provision of academic autonomy of higher educational institutions, freedom of academic thought is currently very high in our country. Besides the issues related to modern legislative provision, no less interesting for scholars and researchers is the system of organization of day-to-day operation of educational institutions, which would ensure the appropriate level of academic autonomy of scholars and professors.

Some aspects of ensuring the academic autonomy of higher educational institutions were studied by: 


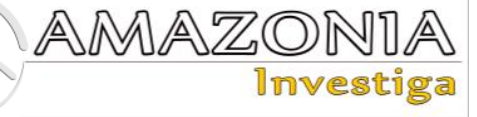

Armbruster C. (Research universities: Autonomy and self-reliance after the entrepreneurial university, 2008);

Bakhrushin V. Ye. (Quality of Higher Education and Modern Approaches to Its Estimation, 2012);

Bilgrami A., Cole J. (Who's Afraid of Academic Freedom? 2015);

Choi $S$. (Identifying indicators of university autonomy according to stakeholders' interests, 2019);

Etomaru I., Ujeyo M. S., Luhamya A., Kimoga J. (Institutional Autonomy: Implications for Teaching and Research in Public Universities in Uganda, 2016);

Kalashnikova S. Luhovyi V. (Development of the Quality Assurance System of Higher Education in Ukraine: information and analytical review, 2015);

Moshman D. (Academic Freedom as the Freedom to do Academic Work, 2017);

Opryshko V. F. (On Higher Education: scientific and practical commentary to the Law of Ukraine, 2015);

Rashkevych Yu. M. (The Bologna Process and a New Paradigm of Higher Education, 2014);

Sinkevych Ye.H. (Regarding the problem of introducing University autonomy: national and foreign experience, 2009);

Steinmetz G. (Scientific Autonomy, Academic Freedom, and Social Research in the United States, 2018)

However, despite the large number of scientific papers on this problem, the issues of determining the content and specific features of academic autonomy of higher educational institutions aimed at streamlining management, regulatory, control and other educational activities in the field of education, remain unresolved at present day.

The objective of the article is to determine the essence, content and specific features of ensuring the academic autonomy of higher educational institutions, as well as propositions and recommendations for improving the legal regulation of higher educational institutions.

\section{Methodology}

The methodological basis of the article was the methods of scientific cognition, which are currently used in conducting scientific research, in particular, the author combined generally scientific and special methods that are used within the relationship and complementarity.

Using the dialectical method the authors have revealed the essence of such concepts as "academic autonomy of educational

institutions", "organizational provision of academic autonomy" and "legal provision of academic autonomy". The use of this scientific method is important because, first of all, modern research is based on a clear understanding of the conceptual apparatus.

The formal and legal method was used while studying scientific sources focused on the issue of ensuring the academic autonomy of higher educational institutions. Due to the analysis of different scientific points of view on the researched matter, the authors were able to rethink more deeply the issues raised in the article.

The bibliographic method provided the authors with the opportunity to select the necessary number of scientific sources focused on the issue of ensuring the academic autonomy of higher educational institutions.

Scientific works of specialists in the field of administrative law and other branches of legal sciences became the scientific and theoretical basis for the article.

\section{Results and discussion}

Observing the intensive movement of Ukrainian society towards full integration with the countries of the European Union, thus trying to become a full member of a single European family, we can distinguish a few important steps that must be taken to succeed in the above aspirations. Among the priorities we should name further democratization of all spheres of everyday life of national society, improving the living standards of Ukrainians by ensuring economic growth and financial well-being of citizens, as well as qualitative and fundamentally new reform of the educational system, scientific and research area of the country.

The notion of autonomy can be considered at institutional and individual level (Armbruster, 2008; Etomaru et al., 2016; Moshman, 2017). In the context of our research, we will consider institutional autonomy, namely academic autonomy of higher educational institutions.

In his article Choi S. (2019) to reconcile two different perspectives and come up with a more comprehensive conceptualization of university autonomy by adopting a stakeholder approach in identifying indicators of university autonomy. One perspective views university autonomy as a protection of academic freedom and the other as a performance enhancer. In order to secure public 
support for university autonomy, a strategy to satisfy both perspectives is required.

The institutional autonomy has to do with institution's decision to make independent decisions, to exercise academic freedom and selfgovernance with regard to internal activities. This in turn implies freedom from interference by the state or any other external governing bodies on institutional organization, governance, funding arrangement, the generation of income for its sustainability, recruitment of its staff, admission of students as well as teaching and researching (Etomaru et al., 2016). The crucial aspect of these institutional settings is that they free scientists to pursue questions generated primarily within scientific fields and debates and to do so with longer time horizons (Steinmetz, 2018).

The proven thesis is that no country in the world can be developed and economically prosperous, if it does not have a strong scientific and technological potential, as well as a decent system of training of future professionals. Another issue that is equally related to both the education system and democracy is the issue of academic autonomy. The latter is defined by modern legislation of Ukraine (Law of Ukraine "On Higher Education", 2014) as autonomy, independence and responsibility of higher educational institutions in making decisions regarding the development of academic freedoms, organization of educational process, research activities, internal management, economic and other activities, independent selection and placement of personnel within the limits established by this law.

It has been also determined that the state policy in the field of higher education is ensured through the development of autonomy of higher educational institutions and academic freedom of the participants in the educational process. The autonomy of higher educational institutions is in dire need of self-organization and selfregulation, which are open to criticism, serve the public interest, establish the truth about the challenges facing the state and society, are transparent and public (paragraph 5 of the Art. 3). Autonomy and self-government are the principles of higher educational institution (paragraph 1, Part 1 of the Art. 32). The content of the autonomy of higher educational institutions is their right to: conduct financial, economic and other activities in accordance with the legislation and the Charter of the higher educational institution (paragraph 22, Part 2 of the Art. 32); to dispose of own revenues (for institutions of higher education of state and municipal forms of ownership), in particular from the provision of paid services (paragraph 23, Part 2 of the Art. 32); to open current and deposit accounts in banks (paragraph 24, Part 2 of the Art. 32).

Thus, there have been recently norms in the current legislation that clearly state the obligations of the state not to interfere in the daily life of higher educational institutions. Moreover, this rule is applied to both state Universities and Academies (there is currently majority of them in Ukraine) and private educational institutions (Opryshko, 2015).

Such changes, being an absolutely everyday phenomenon in the developed and democratic countries of the West, unfortunately, began to face some resistance in Ukraine. Of course, the greatest opposition, among others, was exerted by representatives of the old post-Soviet corrupt elites and the ruling layers of Ukraine. Some state politicians and high-ranking officials did not like the possibility of losing their usual criminal influence on higher educational institutions.

Due to the resistance described above, as well as the opposition to reforms by a large number of employees of education sphere, qualitative changes in the national education system are slower and more difficult than expected.

One of the main reasons for sometimes successful resistance to reforms by the corrupt is the fact that due to the extremely negative legacy that Ukraine inherited from the administrative and command system of the Soviet Union, as well as the lack of radical changes in the educational process during the first quarter of Ukrainian independence, commission of corrupt crimes that are destructive to science on the part of most professors and other employees of educational institutions are not perceived as something criminal or defiant.

For the same reason, a large number of people who have had long and gradual career from ordinary researchers and professors in the Soviet era and the first years of independence, now began to receive positions within higher ranks of the educational hierarchy, prefer to make full use of their administrative powers, and do not want to give them away (Rashkevych, 2014).

Thus, we have a significant number of heads and other officials of higher educational institutions who seek to fix their broad powers and therefore seek to fiercely oppose any democratic reforms. 


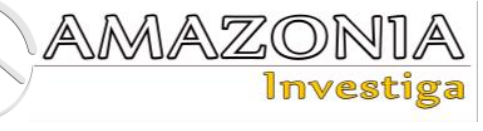

It is worth noting that, despite the sometimes insane pressure of the progressive and democratic part of Ukrainian society, some heads of higher educational institutions are quite successful in maintaining their extremely broad powers, to oppose academic freedom, student self-governance, etc.

This is partly due to the fact that, given the relatively low level of economic well-being of the majority of Ukrainian citizens, high-rank and middle managers in higher education system are able to put pressure and threats on the small number of employees of education sphere, who have the courage to speak out own opinion, which is as a rule contrary to the opinion of the leadership and openly point to specific manifestations of corruption, bribery and embezzlement. Thus, due to the existence of a number of shortcomings in the Ukrainian legal, state and structural systems, employees of the educational sphere, as well as some heads of higher educational institutions, have the opportunity to continue to hold their high positions. After all, they need only a few "useful" relationships in the central office of the relevant Ministry or other state authority. Having such influential relationships, the representatives of the old corrupt system continue quite successfully to hold power and control over the educational process.

However, studying the relevant issues of modern problems in the compliance with academic autonomy, scholars emphasize that the opposite situation has the right to exist in the field of scientific and educational relations. As a rule, it consists of excessive malicious interference of state agencies or services into lawful activities of a higher educational institution. However, the result of the orientation of Ukrainian society to the daily routine of developed countries of the Western Europe, as well as some educational reforms, was the emergence of persons who prefer to perform their professional duties with dignity and transparency on the positions of heads of Ukrainian educational institutions (Bakhrushin, 2012).

It is quite naturally that the original duty of the state in this case should be further consolidation of principles of inviolability of academic autonomy of higher educational institutions and, moreover, active and comprehensive counteraction to attempts of malicious interference of any subjects into lawful daily activity of higher educational institutions. At the same time, it is the duty of society and the public to exert continuous intense pressure on state agencies and political parties of the country in order for the last two institutions to work more effectively in the directions outlined above.

The consequence of such influence of Ukrainian society on the state and its individual rulers was the further adoption of a number of regulations by representatives of the ruling elite, aimed at proper regulation of relations in the field of functioning and protection of academic autonomy in Ukraine. In particular, we can single out among a number of such legal acts the Resolution of the Cabinet of Ministers of Ukraine "On the Establishment of the National Agency for Quality Assurance in Higher Education" dated from April 15, 2015. Among other things, this legal act clearly emphasizes the direct obligation of the Ukrainian state to properly comply with the highest world standards and quality standards in such areas as the provision of educational services, conduction of research activities, accreditation of educational institutions, as well as guaranteeing freedom to freely think and express opinion of all participants in educational and scientific processes without any exception. Significant attention was also paid to ensuring the academic autonomy of higher educational institutions, i.e. the protection of their relative independence within internal daily affairs, which do not contradict Ukrainian law.

It is clear that although the adoption and implementation of such regulations is a significant step towards fundamentally qualitative reform of the national education system, however, it should be noted that the above law and subsequent resolution have a number of contradictions and shortcomings. Among them we can name the lack of sufficient opportunities for the practical implementation of those standards and norms that are prescribed in the above regulatory acts. We talk about scientific and technological gap between the level of equipment of Ukraine and developed countries of the Western Europe and the North America.

In particular, it is confirmed by the lack of advanced modern means for the timely detection of literary pitacy in scientific papers, as well as other falsifications in the Ukrainian state. Thus, despite the positive changes that are to occur in regard to the fact that the above legal acts have been recently entered into force, the current situation with academic autonomy and organizational provision of the educational system still needs much improvement (Kalashnikova, Luhovyi, (2015). 
The Government of Ukraine should take into account the experience of European countries, which recently have taken quite radical steps to improve the provision of autonomy of higher educational institutions. For example, Poland, which faced similar problems as in Ukraine at the end of the XX century, has created the legislative and financial preconditions for the development of academic freedom. It is applied to reducing the annual workload per a professor (300 hours) to the optimal size, increasing wages, stimulating research work (grants, awards), the right of specialized scientific councils to assign academic titles (without Higher Attestation Commission). In turn, the real fight against corruption (the corrupt person is deprived of academic degrees and titles by the court) - created a favorable climate for the development of the University autonomy. The Universities of the Republic of Poland received significant assistance from the European Union, in particular, almost each University received assistance for the construction of new buildings, libraries, sports facilities, etc. (Sinkevych, 2009).

\section{Conclusions}

Despite the relative successes that have been achieved as a result of the introduction of some norms and standards of developed Western countries into national educational system, accompanied by the consolidation of the principles of academic autonomy in legislation, the Ukrainian higher education system still needs new and decisive changes.

Joining the Bologna system was a prerequisite for creating a new model of academic autonomy of higher educational institutions in Ukraine, where the University goes beyond the vertical hierarchy and becomes an institution that independently determines its tasks and is responsible for the results of its activities to the academic and student community.

A characteristic feature of the University's autonomy is its independence from state agencies and organizations, as well as a clear division of powers between the governing agencies of higher educational institutions, etc.

\section{Bibliographic references}

Armbruster, C. (2008). Research universities: Autonomy and self-reliance after the entrepreneurial university. Policy Futures in Education, Vol 6 (4), 372-389.

Bakhrushin, V. Ye. (2012). Quality of Higher Education and Modern Approaches to Its Estimation. Education and Management, Vol. 14. (4), pp. 7-11.

Bilgrami, A. \& Cole J. (eds.) (2015). Who's Afraid of Academic Freedom? New York: Columbia University Press. Recovered from http://cup.columbia.edu/book/whos-afraid-ofacademic-freedom/9780231168809.

Choi, S. (2019). Identifying indicators of university autonomy according to stakeholders' interests. Tert Educ Manag 25, 17-29 https://doi.org/10.1007/s11233-018-09011-y.

Etomaru, I., Ujeyo, M. S., Luhamya, A. \& Kimoga, J. (2016). Institutional Autonomy: Implications for Teaching and Research in Public Universities in Uganda. International Research in Higher Education, Vol 1 (2), 133-142.

Kalashnikova, S. \& Luhovyi, V. (2015). Development of the Quality Assurance System of Higher Education in Ukraine: information and analytical review. Kyiv: NVTs «Priorities». 84 pp.

Moshman, D. (2017). Academic Freedom as the Freedom to do Academic Work. Journal of Academic Freedom, Vol 8, 1-14.

On Higher Education: Law of Ukraine No. 1556VII. Bulletin of Verkhovna Rada of Ukraine, Ukraine, July 1, 2014

On the Establishment of the National Agency for Quality Assurance in Higher Education: Resolution of the Cabinet of Ministers of Ukraine No. 244. Bulletin of Ukraine, Ukraine, April 15, 2015.

Opryshko, V. F. (2015). On Higher Education: scientific and practical commentary to the Law of Ukraine / Under edition of Kyiv: Parliamentary Publishing House. 672 pp.

Rashkevych, Yu. M. (2014). The Bologna Process and a New Paradigm of Higher Education: monograph. Lviv: Publishing House of Lviv Polytechnic. 168 pp.

Sinkevych, Ye. H. (2009). Regarding the problem of introducing University autonomy: national and foreign experience. Scientific works. Vol. 104 (91). pp. 160-163.

Steinmetz, G. (2018). Scientific Autonomy, Academic Freedom, and Social Research in the United States. Critical Historical Studies, Vol 5(2), 281-309. 